\title{
Lectotypification and neotypification of some names in British Hieracium section Foliosa (Asteraceae)
}

\author{
T.C.G. Rich* \\ Cardiff, UK
}

*Corresponding author: T.C.G. Rich tim rich@sky.com

This pdf constitutes the Version of Record published on $26^{\text {th }}$ February 2020

\begin{abstract}
Types are designated for 11 names in Hieracium section Foliosa (Fr.) Arv.-Touv. (Asteraceae). Lectotypes are designated for Hieracium aestivum subsp. subumbellatiforme Zahn, Hieracium corymbosum Fr. var. pycnotrichum W. R. Linton, Hieracium crocatum Fr. var. maritimum F. Hanb., Hieracium latobrigorum forma angustifolium Pugsley, Hieracium obesifolium Pugsley, Hieracium

pseudamplidentatum var. stenophyllum Pugsley, Hieracium rigidum var. tavense Ley, Hieracium strictum var. amplidentatum F. Hanb. and Hieracium strictum var. subcrocatum E. F. Linton. Neotypes are designated for Hieracium inuloides subsp. strictiforme Zahn and Hieracium neocorymbosum var. crocatiforme Pugsley.
\end{abstract}

\section{Introduction}

As part of a revision of British Hieracium section Foliosa (Fr.) Arv.-Touv., I have lectotypified eight names to help fix usage. The types have been selected from material cited in the original descriptions, often with annotations by the original author. Where no original material has been traced but there is a chance that original material may yet come to light, I have neotypified two names. The taxonomy follows Sell \& Murrell (2006).

\section{Typifications}

Hieracium corymbosum Fr. var. pycnotrichum W. R. Linton, in Linton, E. F., An account of British Hieracia 88 (1905). Lectotype (designated here): Gayle Beck, near Hawes, North Yorkshire, September 1888, J. Percival (BM barcode no. BM001003240; isolectotype RNG). When W. R. Linton described var. pycnotrichum, he cited the authority as Dahlstedt taken from Set 4 no. 90 of Dahlstedt's Scandinavian Hieracium species, some of which material it resembled closely. As Dahlstedt's Set and name lacked a description, the name was not validly published, so Linton's short description is the basis of the name as used by Roffey. Linton cited two localities after his description, Bishop Auckland and Hawes. After reviewing the material from these two localities I have concluded they belong to two different species and furthermore the Bishop Auckland material may belong to section Sabauda or section Tridentata rather than section Foliosa. Linton's short description has been checked to which material it most closely applies. The only clear point of difference between the material and the description is that Linton states the panicle 
is close with short peduncles, which fits the material from Hawes better than material from Bishop Auckland (the latter having a large inflorescence and long peduncles); the Hawes material is thus selected as the lectotype. This is the basionym of $H$. pycnotrichum (W. R. Linton) Roffey.

Hieracium corymbosum var. umbellatiforme W. R. Linton, in Linton, E. F., An account of British Hieracia 88 (1905). Lectotype (designated here): Linn of Campsie, Perth, 6 August 1891, W. R. Linton (LIV no. 1974.88.27715, isolectotype LIV no. 1974.88.27716). Linton only cited material from Linn of Campsie, Perth so the material has been selected as the larger of the two specimens in his herbarium. Pugsley (1948) regarded this Linn of Campsie material as ambiguous but it is fairly typical $H$. subumbellatiforme as currently understood.

Zahn (1921-1923) cited Linton's name as the basis of his Hieracium aestivum subsp. subumbellatiforme Zahn in Engler, A. Das Pflanzenreich 77 (IV, 280): 919 (1922) though he incorrectly cited it at species rank rather than varietal rank. In turn, $H$. aestivum subsp. subumbellatiforme Zahn is the basionym of Hieracium subumbellatiforme (Zahn) Roffey, the current name for this taxon.

Hieracium crocatum Fr. var. maritimum F. Hanb., in Journal of Botany 27: 76 (1889). Lectotype (designated here): Sandy cliffs, facing north, Melvich, Sutherland, 22 July 1887, F. J. Hanbury (BM barcode no. BM001194230; isolectotype BM barcode no. BM001003239). The lectotype was selected as the specimen labelled as drawn by Mrs M. J. S. Hanbury for Hanbury's (1889-1898) monograph. This is the basionym of Hieracium maritimum (F. Hanb.) F. Hanb.

Hieracium inuloides subsp. strictiforme Zahn, in Engler, A. Das Pflanzenreich 77 (IV, 280): 906. Leipzig (1922). Neotype (designated here): Inverey, Braemar, S. Aberdeen, 25 July 1889, W. R. Linton, Set of British Hieracia no. 73 (BM barcode no. BM001194231). A neotype is required as the material seen by Zahn was destroyed in the herbarium at Botanischer Garten und Botanisches Museum BerlinDahlem (B) in 1943 during World War 2 (Stafleu \& Cowan, 1988) and I have as yet been unable to trace any other material seen by Zahn. There are probably isoneotypes of this Set in many collections but as Sell (1987) noted that not all of the Linton's sets were uniform these should be checked. This is the basionym of Hieracium strictiforme (Zahn) Roffey.

Hieracium latobrigorum forma angustifolium Pugsley, in Journal of the Linnean Society of London (Botany) 54: 273 (1948). Lectotype (designated here): Crags by the Bagaisteach Burn [now River Vagastie], Altnaharra, Sutherland, 28 July 1887, F. J. Hanbury (BM barcode no. BM001068946). Pugsley did not indicate a type and there are five original sheets from which the lectotype has been selected as the specimen with two identical plants. This is a synonym of Hieracium latobrigorum (Zahn) Roffey (Sell \& Murrell, 2006).

Hieracium neocorymbosum var. crocatiforme Pugsley, in Journal of the Linnean Society of London (Botany) 54: 276 (1948). Neotype (designated here): cliffs of Uamascleit, August 1941, J. W. Heslop Harrison (HAMU). Pugsley (1948) 
cited the holotype for his new variety as follows: "W. A. Clark, Scotasay, 1941 (type); J. W. Heslop Harrison, Uamascleit, 1941; both in Hb. Heslop Harrison". J. W. Heslop Harrison's herbarium was held at Newcastle University (NCE) which has now been transferred to the Hancock Museum (HAMU). John Richards has kindly searched through HAMU but was unable to find Clark's specimen, which may have been destroyed by Clark himself. As Pugsley also cited Heslop Harrison's Uamascleit collection which is extant in HAMU, this is designated as a neotype in case the original holotype is refound. The label on the neotype bears Pugsley's handwritten note " $\mathrm{H}$. neocorymbosum $\mathrm{m}$. v. crocatiforme $\mathrm{m}$." There is a specimen labelled "Isle of Scotasay, Outer Hebrides, July 1941, J. W. Heslop Harrison" in herb. Pugsley (BM) which is not Clark's specimen. This is a synonym of Hieracium subcrocatum (E. F. Linton) Roffey (Sell \& Murrell, 2006).

Hieracium obesifolium Pugsley, in Journal of the Linnean Society of London (Botany) 54: 290 (1948); a lectotype selected by P. D. Sell \& C. West in 1958 but was unpublished and is hereby designated on their behalf: Holm in Burga Water, near Walls, Shetland, 13 August [1902] 1892, W. H. Beeby no. 1634 (SLBI; isolectotypes SLBI, BM barcode no. BM001144074). This is a synonym of Hieracium maritimum (F. Hanb.) F. Hanb. (Sell \& Murrell, 2006).

Hieracium pseudamplidentatum var. stenophyllum Pugsley, in Journal of the Linnean Society of London (Botany) 54: 285 (1948). Lectotype (designated here): By the Spean, near Roy Bridge, West Inverness, 28 July 1896, E. S. Marshall \& W. A. Shoolbred; Linton Set of British Hieracia no. 122 as H. corymbosum var. salicifolium (BM barcode no. BM001068851). There are three original sheets, unusually none of which are annotated as the type by Pugsley; the lectotype is the sheet selected as the one not bearing a label $H$. strictum var. angustum. There are also three sheets in herb. Hanbury which were annotated by Pugsley but which do not have the Set label. This is a synonym of Hieracium subumbellatiforme (Zahn) Roffey (Sell \& Murrell, 2006).

Hieracium rigidum var. tavense Ley, in W. R. Linton, An account of British Hieracia, 83 (1905). Lectotype (designated here): Origin Upper Tawe, Breconshire, garden, 30 July 1902 (CGE). This sheet is annotated by A. Ley with his original Latin description. This is the basionym for Hieracium tavense (Ley) Ley.

Hieracium strictum var. amplidentatum F. Hanb., in Journal of Botany 32: 232 (1894). Lectotype (designated here): River Lyon near its mouth, Breadalbane, 9 August 1890, F. B. White (BM barcode no. BM00052167). This is a synonym of Hieracium subumbellatiforme (Zahn) Roffey (Sell \& Murrell, 2006).

Hieracium strictum var. subcrocatum E. F. Linton, in Journal of Botany 31: 200 (1893). Lectotype (designated here): Grey Mare's Tail, Dumfries, 31 July 1889, E. F. Linton, annotated 'These I have been calling H. strictum Fr. var. subcrocatum, as they appear to be between $H$. strictum and H. crocatum Fr.' (BM barcode no. BM00052201). The lectotype has been selected from the range of syntypes at BM as 
the sheet clearly annotated by Linton with his new name. This is the basionym of Hieracium subcrocatum (E. F. Linton) Roffey.

\section{Acknowledgements}

I would like to thank the Keepers of BM, CGE, E, LIV, RNG and SLBI for access to the collections, Sandy Knapp for very helpful comments on the draft manuscript, John Hunnex for help at BM and John Richards for help with HAMU. This work was funded with a BSBI Science \& Research Grant.

\section{References}

Hanbury, F.J. 1889-1898. An illustrated monograph of the British Hieracia. London: Privately published.

Sell, P.D. 1987. An introduction to the study of the British Hieracia. 1. History and classification. Watsonia, 16: 365-371.

Sell, P.D. \& Murrell, G. 2006. Flora of Great Britain and Ireland, volume 4. Cambridge: Cambridge University Press.

Stafleu, F.A. \& Cowan, R.S. 1988. Taxonomic literature: a selective guide to botanical publications and collections with dates, commentaries and types. Utrecht: W. Junk.

Zahn, K.H. (1921-1923). Compositae - Hieracium, in Engler, A. (ed.) Das Pflanzenreich IV, 280, 77. Leipzig: Wilhelm Englemann.

Copyright retained by author(s). Published by BSBI under the terms of the Creative Commons Attribution 4.0 International Public License.

ISSN: $2632-4970$

https://doi.org/10.33928/bib.2020.02.069 